National Marine

Fisheries Service

NOAA
Fishery Bulletin

2s established in $1881 \approx$
Spencer F. Baird

First U.S. Commissioner of Fisheries and founder of Fishery Bulletin

\begin{abstract}
To better inform stock assessment and management decisions, we used multiple approaches for estimating and comparing species-specific characteristics of the spatiotemporal composition of catch and life history traits of blue rockfish (Sebastes mystinus) and deacon rockfish (S. diaconus). We confirmed the species-level distinction of blue rockfish and deacon rockfish by using the results of genetic identification of individual fish from fin tissue samples and otoliths. Those results reveal the systematic relationships of these species with other rockfish species and enabled an evaluation of differences in distribution and life history (growth) between the 2 species in different management areas. Our evaluation of population structure found no significant differentiation within deacon rockfish and slight differentiation in blue rockfish that may not be biologically significant. Along the U.S. Pacific coast, deacon rockfish accounted for the majority of individuals sampled north of Monterey Bay, California, whereas blue rockfish were the more frequently observed species in waters of Monterey Bay and southern California. Modest but significant differences in growth parameters between the 2 species were observed by species, sex, and state (California or Oregon). The multidisciplinary nature of this study and the techniques and protocols we established provide a model for future research on and assessment of species complexes.
\end{abstract}

Manuscript submitted 27 February 2019. Manuscript accepted 10 February 2020. Fish. Bull. 118:37-50 (2020).

Online publication date: 28 February 2020. doi: 10.7755/FB.118.1.4

The views and opinions expressed or implied in this article are those of the author (or authors) and do not necessarily reflect the position of the National Marine Fisheries Service, NOAA.

\section{Genetic identification of blue rockfish (Sebastes mystinus) and deacon rockfish (S. diaconus) to enable life history analyses for stock assessment}

\author{
Joseph J. Bizzarro (contact author) ${ }^{1,2}$ \\ Elizabeth A. Gilbert-Horvath ${ }^{2}$ \\ E. J. Dick ${ }^{2}$ \\ Aaron M. Berger ${ }^{3}$ \\ Katherine T. Schmidt ${ }^{4}$ \\ Don Pearson ${ }^{2}$
}

\author{
Christine Petersen 5 \\ Lisa A. Kautzi ${ }^{6}$ \\ Rebecca R. Miller ${ }^{1,2}$ \\ John C. Field ${ }^{2}$ \\ John Carlos Garza ${ }^{2,7}$
}

Email address for contact author: joe.bizzarro@noaa.gov

${ }^{1}$ Cooperative Institute for Marine Ecosystems and Climate

University of California, Santa Cruz

110 McAllister Way

Santa Cruz, California 95060

${ }^{2}$ Fisheries Ecology Division

Southwest Fisheries Science Center

National Marine Fisheries Service, NOAA

110 McAllister Way

Santa Cruz, California 95060

${ }^{3}$ Fishery Resource Analysis and Monitoring Division

Northwest Fisheries Science Center

National Marine Fisheries Service, NOAA

2032 SE OSU Drive

Newport, Oregon 97365

\author{
${ }^{4}$ West Coast Region \\ National Marine Fisheries Service, NOAA \\ 650 Capitol Mall, Suite 5-100 \\ Sacramento, California 95814 \\ ${ }^{5}$ Bonneville Power Administration \\ P.O. Box 3621 \\ Portland, Oregon 97232 \\ ${ }^{6}$ Marine Resources Program \\ Oregon Department of Fish and Wildlife \\ 2040 SE Marine Science Drive \\ Newport, Oregon 97365 \\ ${ }^{7}$ Department of Ocean Sciences \\ University of California, Santa Cruz \\ 1156 High Street \\ Santa Cruz, California 95064
}

Modern genetic analyses are uncovering many phenotypically similar but genetically distinct species in otherwise well-characterized groups of organisms. In marine environments, the discovery of cryptic or visually similar species typically is not a function of an infrequent encounter rate, because they often occur in regions that have been heavily exploited and monitored for decades (e.g., Gharrett et al., 2005; Quattro et al., 2013). Several such recent discoveries have been made within rockfishes (Sebastes spp.), an extremely diverse group of more than 100 ecologically and economically important species that are primarily distributed in the northeastern Pacific Ocean (Eschmeyer et al., 2017). This high species diversity is a consequence of a rapid rate of speciation (Johns and Avise, 1998), which is ongoing, with nascent reproductive isolation and incipient species found throughout the genus (Venerus et al., 2013). For example, in the California Current, both the rougheye rockfish (Sebastes aleutianus) and the vermilion rockfish ( $S$. miniatus) were previously considered single species, but each is now known to represent 2 morphologically similar but genetically distinct species: rougheye rockfish (S. aleutianus) and blackspotted rockfish (S. melanostictus) (Gharrett et al., 2005, 2006; Orr and Hawkins, 2008), and vermilion rockfish (S. miniatus) 
and sunset rockfish (S. crocotulus) (Hyde et al., 2008). In a more extreme example from the northwestern Pacific Ocean, the nominal dark-banded rockfish (S. inermis) was discovered to be 3 distinct species that recently separated because of differential resource utilization (i.e., niche differentiation; Kai et al., 2002).

The discovery of unrecognized diversity within species that were previously considered to be monotypic expands our understanding of biodiversity and provides avenues for further study, but it also presents significant management challenges. Species or stocks are commonly used as management units; however, the presence of morphologically indistinguishable but genetically distinct taxa creates heterospecificity that can hamper the design of appropriate management and conservation measures (Tellier et al., 2011). This is particularly true if there are substantive differences between the species in life history (e.g., growth, maturity, or fecundity) or in distribution and habitat associations, differences that could lead to differential exploitation histories and management effectiveness (Cope and Punt, 2011; Cope et al., 2011). Consequently, several authors have emphasized the importance of conducting genetic and life history analyses to disentangle species complexes and to identify divergent lineages and potential subpopulations within rockfish species, to ensure that they are managed appropriately (Buonaccorsi et al., 2005; Tuckey et al., 2007; Hess et al., 2014).

The results of recent genetic analysis indicate that the nominal blue rockfish ( $S$. mystinus) (Jordan and Gilbert, 1881 ) is actually 2 recently diverged but morphologically similar species: the blue rockfish (S. mystinus) and the deacon rockfish (S. diaconus) (Burford et al. ${ }^{1}$; Burford and Bernardi, 2008; Burford et al., 2011a; Frable et al., 2015). Although these species have been difficult to visually distinguish, species-specific differences in coloration, size of the symphyseal knob, ventrum shape, and length of analfin spines align with genetic differentiation (Burford and Bernardi, 2008; Frable et al., 2015).

In addition to genetic and morphological differentiation, differences in geographic distribution, and possibly in depth, have been observed for blue rockfish and deacon rockfish. Deacon rockfish range from the Channel Islands off southern California to Vancouver Island, Canada (Burford, 2009; Frable et al., 2015), and have been commonly reported at depths of 8-72 $\mathrm{m}$ (but have been observed in deeper water at Cobb Seamount, $46^{\circ} 46^{\prime} \mathrm{N}, 130^{\circ} 49^{\prime} \mathrm{W}$; Love ${ }^{2}$ ) (Fig. 1). Blue rockfish range from northern Baja California, Mexico (Klingbeil and Knaggs, 1976), to central Oregon (Frable et al., 2015) and occur from surface waters to seafloor depths of at least $156 \mathrm{~m}$ (Love, 2011; Love ${ }^{2}$ ). Frable et al. (2015) have reported anecdotal evidence that adult deacon rockfish are more frequently found offshore in deeper water

\footnotetext{
${ }^{1}$ Burford, M., M. Carr, and G. Bernardi. 2006. Speciation and genetic structure in a marine fish with an extended pelagic larval phase: an analysis of both the juvenile and adult populations of blue rockfish (Sebastes mystinus). Univ. Calif. Mar. Counc., Coast. Environ. Qual. Initiative Pap. 039, 9 p. [Available from website.]

${ }^{2}$ Love, M. 2018. Personal commun. Mar. Sci. Inst., Univ. Calif., Santa Barbara, Santa Barbara, CA 93106-6150.
}

than adult blue rockfish; however, scant data are available to characterize relative abundance of these 2 species in the broad region of their co-occurrence.

Historical catch and demographic (age and length) data cannot be used to identify blue rockfish and deacon rockfish to the species level, leaving little alternative but to develop a stock assessment of the 2 species together as a complex (Dick et al. ${ }^{3}$ ). Although this species complex constitutes a minor component of commercial landings throughout its range, it has historically been the most frequently landed rockfish stock in the California recreational fishery and is also an important recreational fishery target off Oregon (Miller and Geibel, 1973; Dick et al. ${ }^{3}$ ). Therefore, quantifying differences in growth between the 2 species and evaluating potential spatiotemporal shifts in their relative abundance are critical to alleviating concerns that a single management strategy may not be appropriate for both species.

In this study, we combined genetic identification with otolith-based age and growth analyses to further elucidate differences between blue rockfish and deacon rockfish, describing and comparing patterns of variation in abundance and life history. We used highly informative microsatellite genetic markers to determine the specific identity of numerous biological samples collected over $\sim 40$ years. These identifications enabled estimation of 1) patterns of inter- and intraspecific genetic variation, 2) the contribution of each species to historical and recent fishery landings along the U.S. Pacific coast that were used to evaluate the evidence for spatiotemporal differences in relative abundance, and 3) age and growth parameters for blue rockfish and deacon rockfish that were used to determine if growth differed between species and (broadscale) regions.

\section{Materials and methods}

\section{Genetics}

Material for genetic analyses was obtained from otoliths and fin tissue samples. Otoliths were available from archived samples that were collected from hook-and-line surveys and recreational fisheries sampling off California between 1976 and 1984 and were identified as blue rockfish at the time of collection (Table 1). Otoliths were removed from juvenile and adult fish (number of samples $[n]=1655$ ), then rinsed and air-dried, often leaving a small amount of tissue on the otolith surface from which DNA could be extracted. Fin tissue samples were collected from juveniles and adults off California and Oregon during several surveys and sampling programs between 2009 and

\footnotetext{
${ }^{3}$ Dick, E. J., A. Berger, J. Bizzarro, K. Bosley, J. Cope, J. Field, L. Gilbert-Horvath, N. Grunloh, M. Ivens-Duran, R. Miller et al. 2017. The combined status of blue and deacon rockfishes in U.S. waters off California and Oregon in 2017, 309 p. Agenda item E.8, attach. 9. Pacific Fish. Manage. Counc., Portland, OR. [Available from website.]
} 


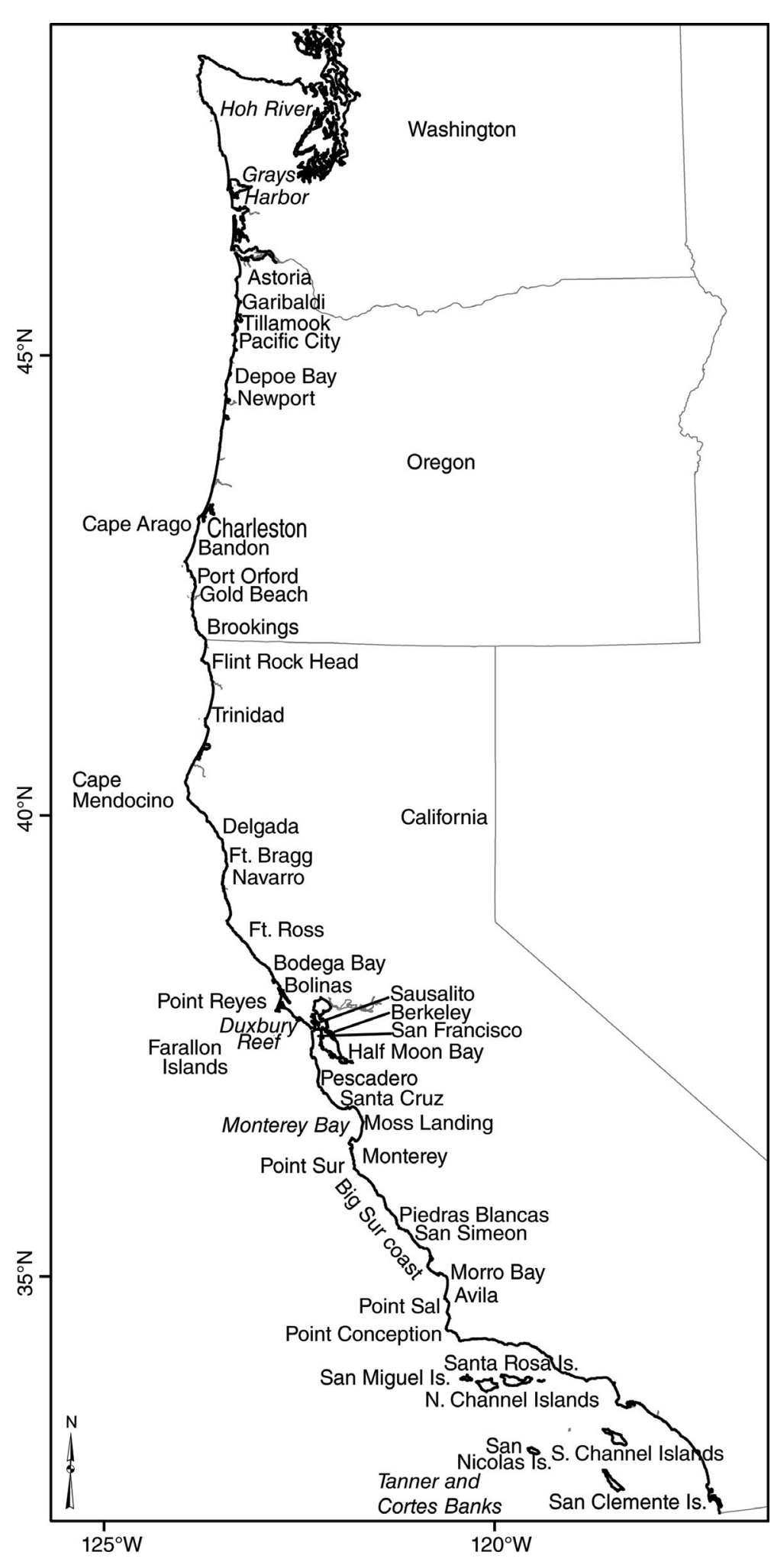

Figure 1

Map depicting the locations of ports of landing along the U.S. Pacific coast where samples of blue rockfish (Sebastes mystinus) and deacon rockfish (S. diaconus) were collected off California, Oregon, and Washington during 2004-2017 and 1976-1984. Other place-names referenced in the text also are shown.
2017, and most individuals were visually identified as either blue rockfish or deacon rockfish (Table 1). Young-of-theyear (YOY; age-0) rockfish were collected off California and Oregon from 2004 to 2016 during mid-water trawl surveys conducted for pelagic rockfish juveniles (Sakuma et al., 2006, 2016). Small pieces of fin tissue were taken from juveniles and adults $(n=1140)$ and from YOY rockfish $(n=192)$, and they were either air-dried or stored in $95 \%$ ethanol. Morphological differences that can be used to distinguish pelagic YOY blue rockfish from deacon rockfish have not been described; therefore, these samples were identified as blue rockfish or deacon rockfish by using genetic analysis (Table 1).

Purified genomic DNA was extracted by using DNeasy 96 Blood and Tissue Kits $^{4}$ (Qiagen Inc., Germantown, MD). The following 9 microsatellite markers were used for genotyping: Seb25, Spi12, Sra6-52, Sth45 (Roques et al., 1999; Sekino et al., 2000; Gómez-Uchida et al., 2003; Buonaccorsi et al., 2004), Seb9, Sme13, Spi10, Sra15-8, and Sth37, the last of which were previously employed by Pearse et al. (2007) for identification of rockfish species. Polymerase chain reaction $(\mathrm{PCR})$ reagent components were as described in Venerus et al. (2013), and the thermal cycling conditions that were used are provided in Supplementary Table 1. The PCR products were electrophoresed on an Applied Biosystems 3730 DNA Analyzer (Thermo Fisher Scientific Inc., Waltham, MA), by using a fragment analysis run module. Allele calling was performed by using Applied Biosystems GeneMapper Software, vers. 4.0 (Thermo Fisher Scientific Inc.).

The genetic species identification process used in this study involved a combination of assignment tests and ancestry analysis. In the assignment tests, genotypes were compared to a reference data set containing visually identified and genetically verified blue rockfish $(n=24)$ and deacon rockfish $(n=26)$, as well as 42 other Sebastes species, including all of those commonly found in the California Current (Supplementary Table 2).

\footnotetext{
${ }^{4}$ Mention of trade names or commercial companies is for identification purposes only and does not imply endorsement by the National Marine Fisheries Service, NOAA.
} 


\section{Table 1}

Region, time period, and life stage (age 0 and age 1 or older [age 1+]) sampled and sample size ( $n$ ) of blue rockfish (Sebastes mysti$n u s$ ) and deacon rockfish (S. diaconus) associated with source information for each study component: genetic, species composition (SppComp), and age and growth (A\&G) analyses. Samples used for the genetic component were genetically identified, whereas samples from the other components were a combination of genetic (1976-1984) and field (2004-2017) identifications. Surveys of pelagic young-of-the-year (YOY, age 0) rockfish were conducted by the National Marine Fisheries Service (NMFS) Southwest Fisheries Science Center (SWFSC) and the Pacific Whiting Conservation Cooperative. Hook-and-line surveys of juveniles and adults were conducted by the California Department of Fish and Wildlife, NMFS Northwest Fisheries Science Center, and the Oregon Department of Fish and Wildlife (ODFW). Unpublished data of S. Beyer were collected by the SWFSC Fisheries Ecology Division.

\begin{tabular}{|c|c|c|c|c|c|c|}
\hline \multirow[b]{2}{*}{ Region } & \multirow[b]{2}{*}{ Source } & \multirow[b]{2}{*}{ Time period } & \multirow[b]{2}{*}{ Life stage } & \multicolumn{3}{|c|}{ Sample size $(n)$} \\
\hline & & & & Genetic & SppComp & $\mathrm{A} \& \mathrm{G}$ \\
\hline \multirow[t]{6}{*}{ California } & Pelagic YOY & 2004-2005, 2013, 2014, 2016 & 0 & 192 & 392 & 0 \\
\hline & Hook and-line surveys & 1976-1977, 2010-2015 & $1+$ & 165 & 184 & 182 \\
\hline & Sport fisheries sampling & $1978,1980-1984$ & $1+$ & 1419 & 311 & 280 \\
\hline & Various surveys & 2004-2006, 2010-2015 & $1+$ & 344 & 463 & 0 \\
\hline & Schmidt, 2014 & 2009-2012 & $1+$ & 780 & 416 & 621 \\
\hline & Beyer, unpubl. data & $2011-2012$ & $1+$ & 0 & 0 & 17 \\
\hline \multirow[t]{4}{*}{ Oregon and Washington } & Pelagic YOY & $2004-2005$ & 0 & 0 & 55 & 0 \\
\hline & Commercial fisheries sampling & $2008-2016$ & $1+$ & 0 & 2753 & 1578 \\
\hline & Sport fisheries sampling & $2008-2016$ & $1+$ & 0 & 7662 & 3747 \\
\hline & ODFW & $2016-2017$ & $1+$ & 87 & 0 & 109 \\
\hline
\end{tabular}

To assess the robustness of these results, 3 assignment analyses were conducted by using 2 software programs, GeneClass2 (Piry et al., 2004) and gsi_sim (Anderson et al., 2008). In GeneClass2, the semi-Bayesian method (Rannala and Mountain, 1997) and the frequency-based method (Paetkau et al., 2004) were employed. For the Paetkau method, the frequency of missing alleles was set to 0.01. Gsi_sim uses a Bayesian simulation method to estimate species (or population) of origin. We employed 25,000 sweeps of the Markov chain Monte Carlo method, following 5000 sweeps of burn-in, to calculate for each individual the posterior probability of membership in each species ( $P$ of $Z$-scores). For both methods, assignment of individuals to reference species (described previously) employed a probability threshold of 0.95 .

The assignment results were then compared to arrive at a consensus species identification for each individual: assignment probabilities of $90 \%$ and above were considered high confidence, whereas probabilities below $90 \%$ were considered low confidence. Because low-confidence assignments are potentially inaccurate, only the high-confidence species assignments were considered as reliable identifications. Individuals that had a low-confidence assignment in one or more of the 3 methods were classified as having low confidence overall. Accordingly, only those individuals with concordant, high-confidence species assignments in all 3 methods were assigned a species identification. This conservative approach was taken to minimize or avoid spurious species assignments and to exclude any potential hybrids.

Multi-locus genotype data were analyzed by using STRUCTURE, vers. 2.3.4 (Pritchard et al., 2000), to determine the degree of genetic distinctiveness of the 2 species. This analysis differs from the assignment analysis because it uses Markov chain Monte Carlo simulation to estimate ancestry of individuals in a fractional manner, given a hypothesis about $K$, the number of genetic groups in the sample as a whole. In this analysis, all samples were considered to be of unknown species affiliation and were not compared to the reference data set as in the assignment analysis, and a location or population prior was not provided. Therefore, the STRUCTURE analysis provided a quasi-independent estimation of genetic species classifications. Analysis parameters included 50,000 burn-in sweeps to ensure an unbiased starting point for the Markov chain, 150,000 iterations without replacement, and 5 replicate runs each for hypothetical $K$ of $2-4$. Although a $K$ value of 2 was assumed a priori to be most likely for these data, higher $K$ values were included to detect genotypes from any other species that might be present in the data set. Then, by using STRUCTURE's fractional ancestry output for a $K$ value of 2 , individuals having >0.90 membership proportion in 1 of the 2 inferred clusters, corresponding to blue rockfish or deacon rockfish, were categorized as members of that cluster.

The final genetic species identification was made on the basis of a comparison of the high-confidence individual assignments and the STRUCTURE ancestry membership results. Species-level identification of individuals with high confidence in only one method (assignment or ancestry) was considered a probable species identification. Individuals with non-concordant results or low-confidence results in both methods were not identified to species and were omitted from further analyses. 
Spatial genetic structure was evaluated at 2 levels: by sampling region within species (blue rockfish, $n=1072$; deacon rockfish, $n=822$ ) and by sampling region between species. Regions were established on the basis of fishing block number assigned by the state of California, fishing port, or latitude and longitude of the collection site (Table 2). Temporal samples were pooled within each region. All available samples, regardless of life stage (adult or juvenile), were included in order to maximize spatial coverage. Because sampling took place over multiple years at most locations, the inclusion of mixed life stages was not expected to bias the regional results. Omitted from this analysis were individuals whose collection site could not be identified or assigned to a fishing block (blue rockfish, $n=16$; deacon rockfish, $n=9$ ) and individuals from 4 regions with too few samples $(n<9)$. Estimates of the pairwise interpopulation fixation index, $F_{\text {ST }}$, were calculated between regions and between the 2 species by region, by using Genetix, vers. 4.05 (Belkhir et al., 2004). Statistical significance was assessed with 4999 permutations, and the resulting $P$-values were adjusted for multiple comparisons by using a strict Bonferroni correction applied to an $\alpha$ of 0.05 . Genetic summary statistics (expected and observed heterozygosity and mean number of alleles per locus) were calculated for each region by using the Microsatellite Toolkit,
MSTools, vers. 3.1 (Park, 2002), an add-in for Microsoft Excel (Microsoft Corp., Redmond, WA).

\section{Species composition}

Total counts of blue rockfish and deacon rockfish were obtained from a variety of fishery-dependent and fishery-independent sources off California, Oregon, and Washington, including visual identification of specimens from the recent time period (2004-2017) and genetic analysis of historical samples (1976-1984). These data then were used to estimate and compare species composition along the U.S. Pacific coast. Samples of juvenile and adult individuals (age 1 or older [age 1+]) were obtained from historical and recent hook-and-line, spearing, and scuba collections conducted in California $(n=1374)$ and Oregon $(n=10,415)$ (Table 1). A comparatively small number of pelagic YOY rockfish were collected by trawling in California $(n=392)$ and Oregon $(n=55)$ during 2004-2016 (Table 1).

The resolution of sample locations was variable and depended on collection method. For the purposes of this evaluation, we assigned the location of samples to the port of landing, a reasonable assumption for specimens sampled primarily from recreational fisheries. The following ports along the coast of Oregon were combined for mapping and

\section{Table 2}

Summary statistics for sampling regions used in analysis of population genetic structure of blue rockfish (Sebastes mystinus) and deacon rockfish ( $S$. diaconus). Material for genetic analyses was obtained from otoliths of blue rockfish and deacon rockfish collected off California (1976-1984) and from fin tissue samples of rockfish caught off California and Oregon (2009-2017). The latitudes for the northern and southern boundaries of the defined regions are given in decimal degrees. Also provided are the number of samples $(n)$ for regions with $>8$ sampled individuals, expected and observed heterozygosity $\left(\mathrm{H}_{\mathrm{E}}\right.$ and $\mathrm{H}_{\mathrm{O}}$, respectively), and mean number of alleles per locus (MNA).

\begin{tabular}{|c|c|c|c|c|c|c|c|}
\hline Region (north to south) & Species & $\begin{array}{l}\text { Northern boundary } \\
\text { (latitude) }\end{array}$ & $\begin{array}{l}\text { Southern boundary } \\
\text { (latitude) }\end{array}$ & $n$ & $\mathrm{H}_{\mathrm{E}}$ & $\mathrm{H}_{\mathrm{O}}$ & MNA \\
\hline Oregon coast & Blue & 44.534 & 42.067 & 16 & 0.5064 & 0.5042 & 4.33 \\
\hline Oregon coast & Deacon & 44.548 & 42.775 & 64 & 0.5176 & 0.5102 & 5.44 \\
\hline Northern California & Deacon & 41.757 & 41.000 & 20 & 0.4976 & 0.4693 & 4.22 \\
\hline Mendocino coast & Deacon & 40.500 & 39.133 & 49 & 0.5097 & 0.4303 & 5.00 \\
\hline Bodega Bay & Blue & 38.467 & 38.167 & 14 & 0.5435 & 0.5659 & 4.22 \\
\hline Bodega Bay & Deacon & 38.422 & 38.037 & 66 & 0.5120 & 0.5084 & 5.78 \\
\hline Farallon Islands & Blue & 37.883 & 37.714 & 33 & 0.5018 & 0.4345 & 5.33 \\
\hline Farallon Islands & Deacon & 37.883 & 37.734 & 99 & 0.5152 & 0.4642 & 6.11 \\
\hline Half Moon Bay & Blue & 37.433 & 37.162 & 145 & 0.5260 & 0.5118 & 8.11 \\
\hline Half Moon Bay & Deacon & 37.388 & 37.163 & 328 & 0.5190 & 0.4879 & 7.44 \\
\hline Monterey Bay & Blue & 36.983 & 36.544 & 367 & 0.4979 & 0.4589 & 8.56 \\
\hline Monterey Bay & Deacon & 36.983 & 36.544 & 136 & 0.5204 & 0.5170 & 6.44 \\
\hline Big Sur coast & Blue & 36.474 & 36.031 & 38 & 0.4877 & 0.4679 & 5.22 \\
\hline Big Sur coast & Deacon & 36.564 & 36.300 & 21 & 0.5477 & 0.5248 & 5.22 \\
\hline Morro Bay & Blue & 35.703 & 35.000 & 172 & 0.4889 & 0.4616 & 7.56 \\
\hline Morro Bay & Deacon & 35.703 & 35.000 & 30 & 0.5035 & 0.5254 & 5.00 \\
\hline Santa Barbara Channel & Blue & 34.442 & 34.349 & 18 & 0.4293 & 0.4405 & 4.44 \\
\hline Northern Channel Islands & Blue & 34.141 & 33.883 & 178 & 0.4755 & 0.4475 & 7.11 \\
\hline Northern Channel Islands & Deacon & 34.141 & 34.017 & 9 & 0.5696 & 0.6497 & 3.67 \\
\hline Southern California shore & Blue & 34.007 & 32.806 & 21 & 0.5183 & 0.5351 & 5.11 \\
\hline Southern Channel Islands & Blue & 33.495 & 32.450 & 70 & 0.4833 & 0.4481 & 6.22 \\
\hline
\end{tabular}


analysis: Tillamook (ports Astoria, Tillamook, Pacific City, and Garibaldi), Newport (ports Depoe Bay and Newport), Bandon (ports Bandon and Charleston), and Brookings (ports Brookings, Gold Beach, and Port Orford) (Fig. 1). The following ports and locations off the coast of California were combined for mapping and analysis: Point Reyes (ports Point Reyes and Fort Ross), Bolinas (ports Bolinas and Duxbury Reef), San Francisco Bay (ports Berkeley, San Francisco, and Sausalito), Santa Cruz (ports Santa Cruz, Davenport, and Moss Landing), Cortes Bank (ports Cortes and Tanner Banks), and the Southern California Bight (Fig. 1).

Species compositions of age- 0 and age-1+ blue rockfish and deacon rockfish at ports in California and Oregon were summarized and displayed visually by using geographic information system software (ArcMap, vers. 10.4.1, Esri, Redlands, CA). In central California, for which data exist from historical and recent collections (Table 1), the relative percentage of blue rockfish and deacon rockfish was calculated for each time period.

Spatiotemporal patterns in species composition were investigated and compared with results from generalized linear models (GLMs) and generalized linear mixed models (GLMMs) by using a subset of data from port sampling in California. Species composition data (observed counts of each species) from central California were divided into the following groups, or port complexes, by proximity: Morro Bay Complex (from San Simeon to Avila), Monterey Bay Complex (from Monterey to Santa Cruz), and San Francisco Bay Complex (from Half Moon Bay to Bolinas). Data from southern California were not analyzed because deacon rockfish rarely were observed, whereas data from northern California were excluded because the sample size $(n=71)$ was considered inadequate to reliably characterize species composition. Count data by species were fit by using a binomial GLM with a logit-link function and a logit-normal GLMM with observation-level random effects to determine if species compositions were influenced by spatial location or temporal occurrence. In these models, the number of positive occurrences of blue rockfish was considered the response variable, and location (Morro Bay Complex, Monterey Bay Complex, or San Francisco Bay Complex) and time period (historical, 1976-1984, or recent, 2004-2014) were included as categorical covariates. Model diagnostics were conducted to evaluate fit, and the Akaike information criterion (AIC) was used to select the best model for the data (Akaike, 1974). All analyses and diagnostics were conducted with statistical software R, vers. 3.3.2 ( $\mathrm{R}$ Core Team, 2016).

\section{Age and growth}

Numerous studies evaluated age and growth of the blue rockfish and deacon rockfish complex prior to the description of deacon rockfish as a separate species, by using various methods (e.g., surface ages versus break and burn; for a review, see Laidig et al., 2003) and structures (e.g., scales or otoliths). Our species-specific data on age and growth were differentiated by using high-confidence genetic identifications for samples from California and visual field identifications for samples from Oregon, where they are considered reliable (Hannah et al. ${ }^{5}$ ).

Age estimates were derived from otoliths that were collected from recreational fisheries and research surveys in waters of California (Table 1). Otoliths collected between 1976 and 1984 were from fish identified to species with genetic analysis, whereas most contemporary samples (2005-2015) were from fish that were visually identified and then had their identity confirmed through genetic analyses. All otoliths of each species were aged by using the break-and-burn method (Beamish, 1979; Kimura et al., 1979), including otoliths from relatively small individuals that may have also been aged with surface reads.

Otoliths from blue rockfish and deacon rockfish off Oregon were primarily collected from fish taken by the recreational ocean-boat and commercial fleets, mainly by using hook-and-line methods (Table 1), but some otoliths were from fish collected during surveys that were conducted between December 2016 and February 2017 to target small fish $(<24 \mathrm{~cm}$ fork length $[\mathrm{FL}])$ that were poorly sampled by fishing fleets. These otoliths also were aged by using the break-and-burn method, except for a few otoliths collected from small, young individuals.

Aging error was evaluated by comparing estimates from otoliths that had been independently read twice by the same reader (within-reader variation) and by 2 different readers (between-reader variation). To evaluate withinreader aging error for samples from California, 587 otoliths were aged twice by the same person (blind reads), and the results were compared with age bias plots (after Campana et al., 1995). Within-reader aging error for samples from Oregon was assessed in the same manner by randomly selecting and comparing age estimates from $20 \%$ of all aged otoliths $(n=1123)$. Between-reader aging error was evaluated for California and Oregon readers by comparing final reads for each region with a subset of 257 otoliths.

Age and length data for all species, both sexes, and different regions were fit by using the von Bertalanffy (1957) growth function:

$$
L_{\mathrm{t}}=L_{\infty}\left(1-e^{-k\left(t-t_{0}\right)}\right)
$$

where $L_{\mathrm{t}}=\mathrm{FL}$ (in millimeters) of fish at a given age $t$ (in years);

$L_{\infty}=$ theoretical average maximum length (in millimeters);

$k=$ growth coefficient (per year); and

$t_{0}=$ theoretical age at size zero.

The $L_{\infty}, k$, and $t_{0}$ were estimated by using the nls (nonlinear least squares) function in R. The AIC was used to evaluate the relative fit of different regression models.

\footnotetext{
${ }^{5}$ Hannah, R. W., D. W. Wagman, and L. A. Kautzi. 2015. Cryptic speciation in the blue rockfish (Sebastes mystinus): age, growth and female maturity of the blue-sided rockfish, a newly identified species, from Oregon waters. Oregon Dep. Fish Wildl., Fish Div., Inf. Rep. 2015-01, 24 p. [Available from website.]
} 
Four separate comparisons were made to assess potential sources of variability in age and growth parameters. The initial baseline analysis pooled the 2 species and states (Oregon and California) and compared only sexes. Subsequent analyses added categorical covariates for species and then state to the original model. Finally, to assess spatial differences in age and growth of female blue rockfish within the region of California, we evaluated data that were collected from specimens sampled north of Point Conception by Schmidt (2014) and sampled south of Point Conception in a hook-and-line survey (for a description of survey methods, see Harms et al., 2008).

\section{Results}

\section{Genetics}

Fin tissue samples yielded a much greater proportion of sufficient data for species identification than did otoliths, but species discrimination was reliable regardless of source material (Table 3). Most tissue samples produced sufficient genetic data for identification, and $91.2 \%$ of them were either verified $(83.6 \%)$ or probable $(7.6 \%)$ blue rockfish or deacon rockfish. In contrast, less than half of the otolith samples yielded sufficient data for identification, with $33.8 \%$ verified and $8.7 \%$ probable identifications (Table 3). Failure to yield a consensus species identification could have been caused by a variety of factors, such as poorly preserved DNA, missing data, or individuals of other Sebastes species visually misidentified as blue rockfish or deacon rockfish.

\section{Table 3}

Comparison of species identification results obtained from genetic analysis of recent fin tissue (2009-2016) and historical otolith (1976-1984) samples of blue rockfish (Sebastes mystinus) and deacon rockfish (S. diaconus) off the Pacific coast of the United States. See the "Materials and methods" section for criteria used to assign verified and probable identifications to other Sebastes species. The values in the last row (None) are for samples for which no species assignment was made, because of ambiguous or discrepant results or missing data. $n=$ number of samples.

\begin{tabular}{lrrrrr}
\hline & \multicolumn{2}{c}{ Fin tissue } & & \multicolumn{2}{c}{ Otolith } \\
\cline { 2 - 3 } \cline { 6 - 7 } Species identification & \multicolumn{1}{c}{$n$} & $\%$ & & $n$ & $\%$ \\
\hline Blue rockfish (verified) & 630 & 46.5 & & 309 & 18.9 \\
Deacon rockfish (verified) & 503 & 37.1 & & 243 & 14.9 \\
Blue rockfish (probable) & 68 & 5.0 & & 90 & 5.5 \\
Deacon rockfish (probable) & 35 & 2.6 & & 52 & 3.2 \\
Other Sebastes species & 8 & 0.6 & & 17 & 1.0 \\
None & 112 & 8.3 & & 920 & 56.4 \\
Total & 1356 & 100 & & 1631 & 100 \\
& & & & &
\end{tabular}

Concordance between visual and genetic identifications was high, indicating that blue rockfish and deacon rockfish can be reliably distinguished in the field. Visual and genetic identifications matched in $96.3 \%$ of samples for which both were available $(n=1042)$. Discrepant visual identifications were skewed toward deacon rockfish being identified as blue rockfish $(n=33)$, whereas only 2 blue rockfish were visually identified as deacon rockfish. Two individuals that were visually identified as potential hybrids were genetically identified with high confidence as deacon rockfish.

Distributions of pairwise $F_{\mathrm{ST}}$ estimates within and between species displayed a distinctly bimodal pattern with nonoverlapping distributions (Supplementary Figure). Mean pairwise $F_{\mathrm{ST}}$ was at least 2 orders of magnitude larger among interspecific comparisons (0.1545 [standard deviation (SD) 0.0216]) than among the intraspecific comparisons, for which mean pairwise $F_{\mathrm{ST}}$ was almost zero (blue rockfish: 0.0057 [SD 0.0123]; deacon rockfish: 0.0007 [SD 0.0042]). All 110 of the interspecific $F_{\text {ST }}$ comparisons differed significantly from zero following Bonferroni correction, whereas only 5 of 55 intraspecific comparisons for blue rockfish differed significantly and none of the 45 pairwise comparisons for deacon rockfish were significant. For blue rockfish, 4 of the significantly different within-species comparisons involved the location of Half Moon Bay and regions more to the south, and the comparison for the regions of Oregon and the northern Channel Islands also differed significantly.

Measures of genetic diversity were similar both between blue rockfish and deacon rockfish within the same region and between geographic regions within each species (Table 2). In 2-tailed $t$-tests for independent means, observed heterozygosity $\left(\mathrm{H}_{\mathrm{O}}\right)$ and mean number of alleles per locus (MNA) did not differ significantly between the 2 species $\left(\mathrm{H}_{\mathrm{O}}, t=-1.307, P=0.207\right.$; MNA: $\left.t=0.982, P=0.338\right)$. In addition, there was no significant correlation between latitude and $\mathrm{H}_{\mathrm{O}}$ within blue rockfish (coefficient of correlation $[r]=0.325, P=0.329)$ or deacon rockfish $(r=-0.584$, $P=0.077$ ), consistent with intraspecific genetic homogeneity over a broad geographic scale.

\section{Species composition}

The relative proportion of deacon rockfish increased with latitude and dominated samples from north of Monterey Bay, whereas blue rockfish were caught more frequently farther south (Fig. 2). From Pescadero, California, to Hoh River, Washington, $81.1 \%$ of YOY $(n=322)$ and $85.7 \%$ of age- $1+$ individuals ( $n=10,889)$ were deacon rockfish, whereas from south of Pescadero, $71.2 \%$ of YOY $(n=125)$ and $87.0 \%$ of juveniles and adults $(n=900)$ were blue rockfish. Deacon rockfish were especially dominant off Oregon and Washington (age 0: $98.2 \%, n=55$; age $1+: 86.1 \%$, $n=10,415$ ) but were rarely encountered south of Point Conception (age 0: 0.0\%, $n=24$; age 1+: 2.7\%, $n=293$ ).

Comparisons of age-1+ catch composition indicated significant spatial differences in the relative proportions of blue rockfish and deacon rockfish (Fig. 3). Models that 


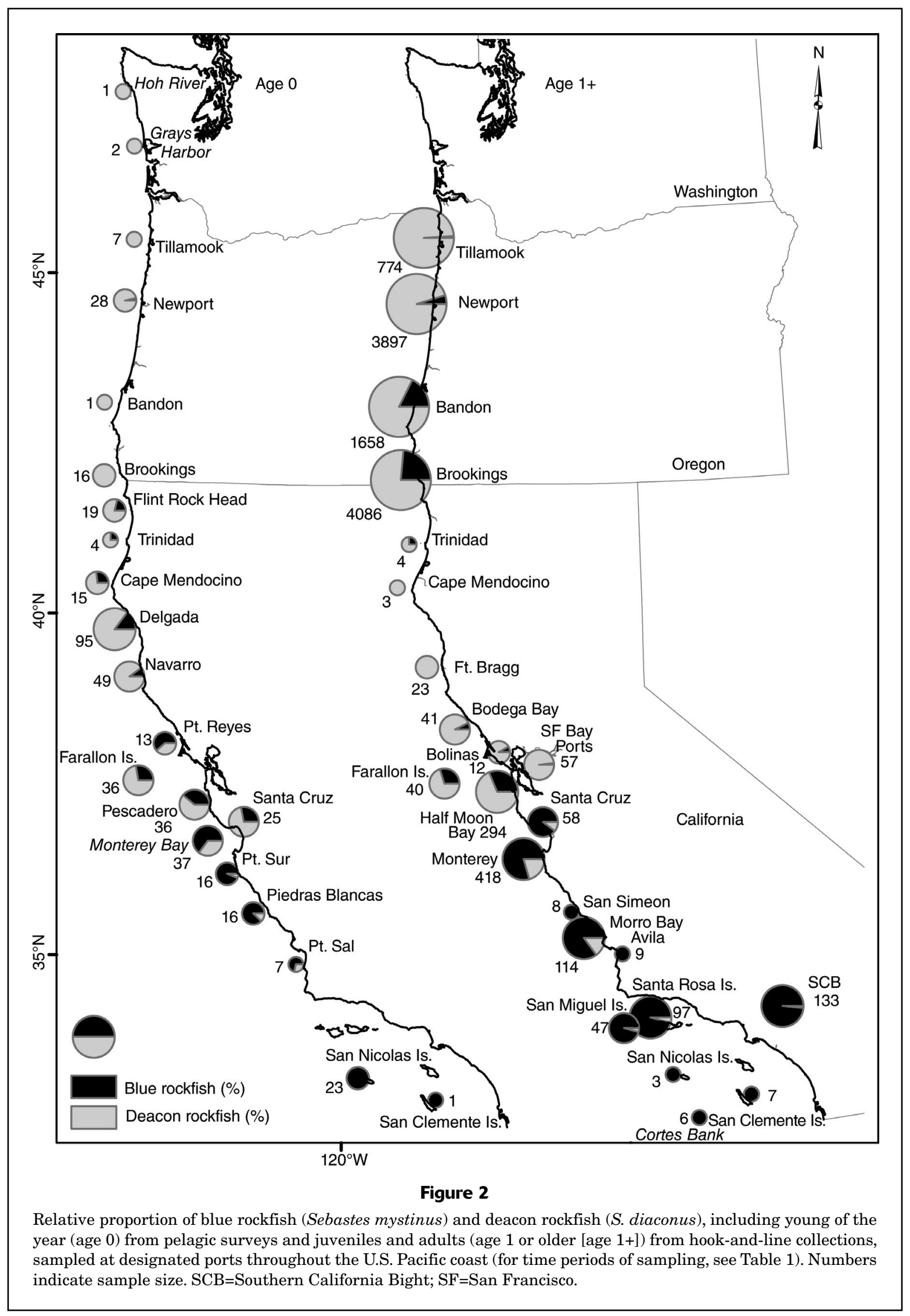




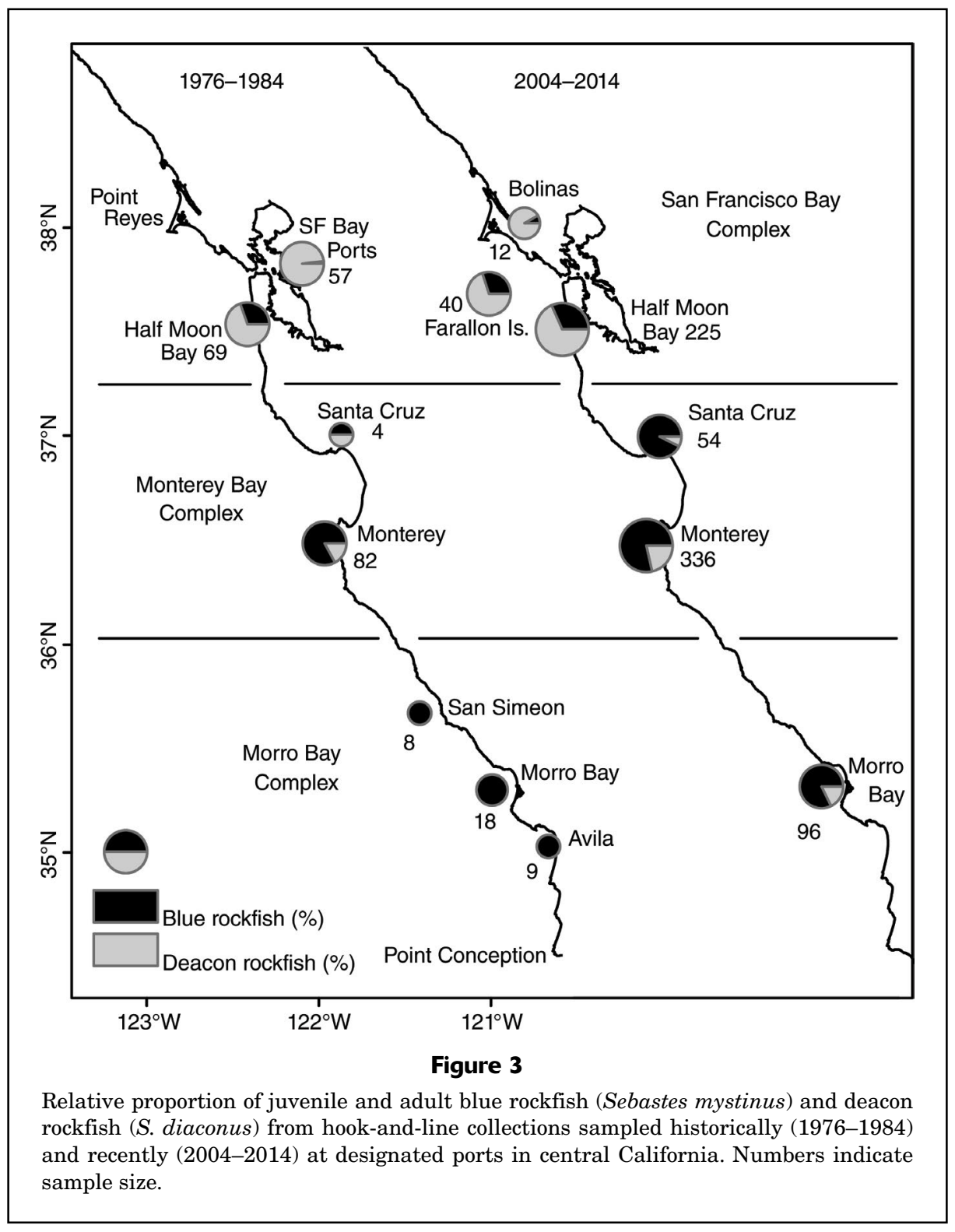

incorporated observation-level random effects and included only location (AIC: 98.5) or location and time period (difference in AIC values [ $\triangle \mathrm{AIC}]: 1.9$ ) as covariates had similar fits that were not improved when an interaction term was added ( $\triangle \mathrm{AIC}: 22.2$ ). A significantly greater proportion of blue rockfish was caught in the Monterey Bay Complex $(80.7 \%, n=476)$ than in the San Francisco Bay Complex (26.3\%, $n=403) \quad(Z=-5.41$, $P<0.001)$; however, no significant difference in proportion of blue rockfish was found between catch compositions from the Monterey Bay and Morro Bay Complexes (87.0\%, $n=131, Z=1.57, P=0.110$ ). The overall proportion of blue rockfish was not significantly different between historical (1976-1984) and recent (2004-2014) time periods $(Z=0.135, P=0.892)$.

\section{Age and growth}

The most parsimonious age and growth model for all data from both species included all 3 distinguishing variables: species, sex, and state (Table 4). Speciessex and sex (only) models had relatively poor fits, but results from them are provided for comparative purposes (Table 4). For both species in both states, females grew slower and reached larger maximum sizes than males (Table 4, Fig. 4). Female blue rockfish and female deacon rockfish from Oregon also had similar estimated growth rates and maximum FLs (Table 4). Off California, both sexes of deacon rockfish grew to larger sizes at slower rates than did both sexes of blue rockfish (Table 4, Fig. 4). 


\section{Table 4}

The von Bertalanffy growth function (VBGF) parameters and sample sizes $(n)$ for age and growth models that incorporate different combinations of species, sex, and state for blue rockfish (Sebastes mystinus), deacon rockfish (S. diaconus), and both species. Samples were collected off California and Oregon during 1976-1984 and 2009-2017. The VBGF parameters are the theoretical average maximum length $\left(L_{\infty}\right)$, annual growth coefficient $(k)$, and theoretical age at size zero $\left(t_{0}\right)$. Sex and region information were combined for blue rockfish sampled off California. Models were compared by using Akaike information criterion (AIC). Values for $L_{\infty}$ are give in fork length in centimeters. Also provided is the difference in AIC values between each model and the best fit $(0)$ model $(\triangle \mathrm{AIC})$.

\begin{tabular}{|c|c|c|c|c|c|c|c|c|}
\hline Model & $\Delta \mathrm{AIC}$ & Species & Sex & State & $n$ & $L \infty$ & $k$ & $t_{0}$ \\
\hline \multirow{2}{*}{ California-Oregon (Sex) } & \multirow{2}{*}{1567.9} & Both & Female & California, Oregon & 4989 & 37.5 & 0.21 & -1.44 \\
\hline & & Both & Male & California, Oregon & 1545 & 30.3 & 0.38 & -0.39 \\
\hline \multirow[t]{4}{*}{ California-Oregon (Species-Sex) } & \multirow[t]{4}{*}{1239.6} & Blue & Female & California, Oregon & 1463 & 37.1 & 0.19 & -1.84 \\
\hline & & Blue & Male & California, Oregon & 217 & 30.5 & 0.30 & -0.76 \\
\hline & & Deacon & Female & California, Oregon & 3526 & 37.8 & 0.22 & -1.27 \\
\hline & & Deacon & Male & California, Oregon & 1328 & 30.3 & 0.39 & -0.38 \\
\hline \multirow[t]{8}{*}{ California-Oregon (Species-Sex-State) } & \multirow[t]{8}{*}{0.0} & Blue & Female & Oregon & 931 & 38.0 & 0.20 & 2.13 \\
\hline & & Blue & Male & Oregon & 131 & 30.6 & 0.34 & -1.02 \\
\hline & & Blue & Female & California & 532 & 35.5 & 0.15 & -3.04 \\
\hline & & Blue & Male & California & 86 & 31.0 & 0.19 & -2.30 \\
\hline & & Deacon & Female & Oregon & 3198 & 37.8 & 0.21 & -1.51 \\
\hline & & Deacon & Male & Oregon & 1174 & 30.1 & 0.40 & -0.69 \\
\hline & & Deacon & Female & California & 328 & 41.3 & 0.13 & -2.81 \\
\hline & & Deacon & Male & California & 154 & 33.8 & 0.16 & -2.91 \\
\hline California (Sex) & 0.0 & Blue & Female & California & 404 & 34.5 & 0.17 & -2.64 \\
\hline \multirow[t]{2}{*}{ California (Sex-Region) } & \multirow[t]{2}{*}{60.1} & Blue & Female & Northern California & 292 & 34.2 & 0.17 & -2.44 \\
\hline & & Blue & Female & Southern California & 112 & 37.3 & 0.13 & -5.08 \\
\hline
\end{tabular}

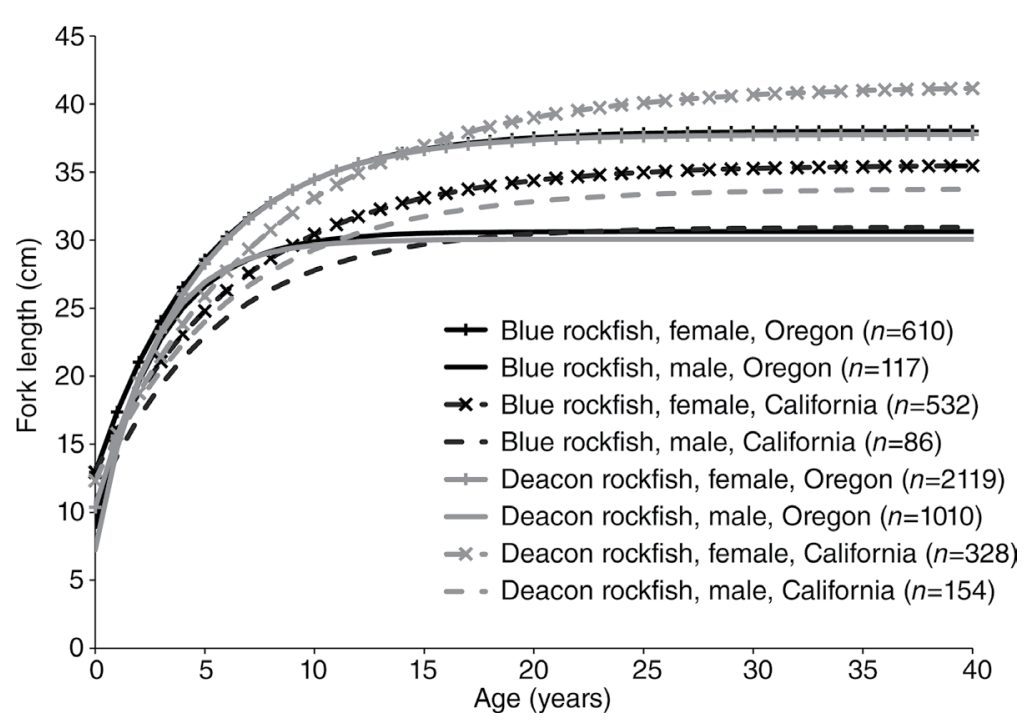

Figure 4

Fitted von Bertalanffy growth curves for female and male blue rockfish (Sebastes mystinus) and deacon rockfish (S. diaconus) collected from waters of either California or Oregon. For time periods of sampling, see Table 1. $n=$ number of samples.
Female blue rockfish in southern California grew slower and reached slightly larger maximum sizes than female blue rockfish in northern California (Table 4); however, the more parsimonious model combined fish from both regions (Table 4). The combined model was heavily influenced by the larger sample size in the northern California data set, and the growth parameter estimates of the statewide and northern California models were nearly the same (Table 4).

\section{Discussion}

The use of genetic techniques to provide species identification of archived samples and to validate recent field identifications of blue rockfish and deacon rockfish enabled the separate estimation and comparison of biological traits for these 2 sister species. The application of this information to a recent stock assessment for the blue rockfish and deacon rockfish complex provided contextual information for the 
interpretation of reference points and uncertainty in the stock assessment model results and for the development of management recommendations and research needs (Dick et al. ${ }^{3}$ ). Furthermore, the high concordance between visual and genetic identification provides more evidence that blue rockfish and deacon rockfish can be reliably distinguished in the field by using morphological characteristics and coloration (Burford and Bernardi, 2008; Frable et al., 2015). The methods used in our study could be applied to other groups to estimate biological traits for taxa that are part of species complexes, particularly in situations in which recent sample data are sparse but archived collections of otoliths or other material exist to inform growth and demographic studies.

The results of our population genetic analyses confirm blue rockfish and deacon rockfish as a pair of significantly diverged species with limited intraspecific geographic structure (e.g., little to no population structure within the species range). Geographically, blue rockfish and deacon rockfish are highly differentiated from each other in regions throughout California and Oregon. Within species, however, deacon rockfish appear to be panmictic from southern California to central Oregon, indicating high gene flow over $\sim 1300 \mathrm{~km}$. For blue rockfish, although high gene flow also was the dominant pattern, some potential genetic structure was found, with significant differentiation between Oregon and the Channel Islands (the most geographically distant sampling sites in this study). In addition, Half Moon Bay was differentiated from most regions between the Farallon Islands off San Francisco and southern California (a distance of $\sim 430 \mathrm{~km}$ ). However, no evidence indicates a straightforward pattern of isolation by distance. Our results are generally consistent with a model of gene flow over hundreds of kilometers. The extent to which factors such as genotyping error and pooling of individuals over collection years affect our results is unclear. Further research might examine fine-scale population genetic patterns (e.g., temporal, latitudinal, depth, and distance from shore) within this species to validate and identify the drivers of this apparent differentiation. In addition, whether blue rockfish and deacon rockfish interbreed when they are sympatric is not known, and future studies may attempt to identify potential hybrids between the 2 species.

The high concordance between visual and genetic species identification in this study demonstrates the efficacy of distinguishing blue rockfish and deacon rockfish by either method alone. However, there is room for improvement in both methods. Additional distinguishing characteristics for deacon rockfish might improve the accuracy of visual identification in the field; in contrast, blue rockfish were only rarely misidentified. The genetic species identification process was designed to be rigorous, but the 9-marker species identification panel was developed by using high-quality DNA extracted from modern samples. Degradation and cross-contamination of DNA among the historical samples rendered many such samples unusable, leading to the use of greatly increased sample sizes to compensate for widespread instances of missing data. Data derived from low-quality samples are prone to allelic dropout and elevated genotyping error; hence, a conservative approach was taken during the species identification process to account for these limitations and for the lack of corroborative visual identifications for historical samples.

Blue rockfish and deacon rockfish are sympatric between Morro Bay and central Oregon, but there appears to be an abrupt shift in relative abundance between Monterey Bay and San Francisco Bay. Previous work has indicated that adults of both species had a high degree of spatial overlap and similar relative abundance in the approximately 450-km stretch of coast from Cape Arago, Oregon, to Cape Mendocino, California (Burford, 2009), and that the distribution of newly recruited juveniles shifted slightly to the south of the adult distribution (Burford et al., 2011b). However, several differences between this and prior studies may confound direct comparisons, including collection years (1976-1984 and 2004-2017 in our study versus 1999-2002 in previous studies), methods (scuba, spearing, and hook and line in our study and hook and line in prior studies), and sampling locations (Burford et al. ${ }^{1}$; Burford et al., 2011b). Burford et al. (2011b) suggested that temporal differences in species composition between life stages provide evidence of a southern shift in distribution of deacon rockfish during cold-water years. More data are needed to determine and compare the distribution, abundance, and habitat associations of these species, especially where they co-occur in similar relative abundance and particularly in the broad and poorly sampled region from north of San Francisco to the border of California and Oregon.

There are several sources of potential bias that should be considered when evaluating our species composition results. Data were collected opportunistically from a variety of ports and integrated across seasons and years, adding a degree of spatiotemporal variability that was unaccounted for in the calculation of descriptive statistics. Although the results of regression modeling indicate significant spatial and spatiotemporal differences, relatively few samples were collected for statistical comparisons, especially during the historical time period. Our relatively simple model also did not account for all sources of variability (e.g., fishing depth, hook type, size, selectivity, or bait type), increasing the possibility of Type 1 error.

The results of this study provide species-specific age and growth information for blue rockfish and deacon rockfish by sex and state, filling a life history data gap that has important management implications. Several previous age and growth studies were conducted on blue rockfish and deacon rockfish prior to the description of the complex as 2 separate species, with 4 of these conducted in California (Miller and Geibel, 1973; MacGregor, 1983; Karpov et al., 1995; Laidig et al., 2003) and 2 studies conducted in Oregon (McClure, 1982; Hannah et al. ${ }^{5}$ ). Because age and growth parameters varied between blue rockfish and deacon rockfish in our study and between sexes of the species complex in prior studies (McClure, 1982; Laidig et al., 2003), direct comparisons of age and growth estimates are limited to those studies that fit separate growth models for females and males.

We found that, in waters of California, deacon rockfish grow to larger sizes at slower rates than blue rockfish. However, our species-specific results are generally consistent 
with those of Laidig et al. (2003) for the blue rockfish and deacon rockfish complex; they found that males $(k=0.195)$ grew faster than females $(k=0.149)$ but that females reached larger maximum sizes. The oldest assigned and maximum predicted ages (at $L_{\infty}$ ) were greater in Laidig et al. (2003) than in our study, most likely because Laidig et al. (2003) included several very large fish ( $>40 \mathrm{~cm}$ FL) in their analysis, whereas such fish were largely absent from our samples.

Growth rates of the blue rockfish and deacon rockfish complex have been reported to be faster for individuals collected off Oregon (McClure, 1982; male: $k=0.23$; female: $k=0.31$ ) than for those collected off California (Laidig et al., 2003), consistent with our results. Concordance with the results of Hannah et al. ${ }^{5}$ is unsurprising because their age estimates compose a portion $(\sim 10 \%)$ of our data for deacon rockfish. However, McClure (1982) reported much larger sizes at age, possibly as a result of the use of surface reads instead of the break-and-burn technique (Laidig et al., 2003; this study), as surface reads may underestimate age in rockfish species (Chilton and Beamish, 1982; Munk, 2001).

Some caveats and considerations are provided to facilitate a thorough evaluation of the results of our age and growth analyses. We had low sample sizes for some of the modeled populations, including male blue rockfish in California and Oregon and deacon rockfish in California, and samples of both species were particularly sparse between San Francisco and the Oregon border. There also were few small juveniles in Oregon and large adults in California, potentially contributing to greater uncertainty in our region-specific estimates of growth parameters $\left(t_{0}\right.$ and $L_{\infty}$, respectively). Finally, although there was substantial agreement among ages between readers from California and Oregon (49\% agreement to the same year), some bias was apparent, with $38 \%$ of age assignments reflecting an older age estimated by the California reader relative to the estimate by the Oregon reader (Dick et al. ${ }^{3}$ ). Because the age estimates were not validated by other methods, the accuracy of each set of reads cannot be evaluated.

Despite these caveats, our results provide a better understanding of the population genetics and life histories of a closely related pair of common, nearshore rockfish species and establish a foundation for future research and management of each species. It has been argued that managing species as a complex, because of data limitations or other factors, is reasonable only if the constituent species have similar life histories and if there is some realistic expectation that they will share similar population responses to fishing (Shertzer and Williams, 2008; Jiao et al., 2009; Cope et al., 2011). When there is evidence to indicate substantially different life histories, and therefore productivity levels, treating the complex as a single stock could raise significant conservation concerns because estimated fishing rates could be unsustainable for the less productive of the constituent species.

The most recent stock assessment treated blue rockfish and deacon rockfish as a complex because of a paucity of reliable species-specific life history, distribution, and abundance data and because of the inability to distinguish the 2 species in historical catch and landings data. The ability to demonstrate that growth was similar for the 2 species (within assessment areas) and to demonstrate that species composition did not vary significantly over time near the region where the greatest shift in abundance has been reported to occur (Dick et al. ${ }^{3}$ ) were key factors in the adoption of the species complex assessment. Despite these findings, the recent assessment was considered to be more uncertain than a typical single-species stock assessment, as has been the case for other stock assessments of multispecies complexes (e.g., Hicks et al., 2014). As a result, uncertainty buffers between allowed biological catches and overfishing limits that were greater than those for single-species assessments based on data of comparable quality $\left(\mathrm{NMFS}^{6}\right)$ were recommended and adopted by fishery managers.

The information presented from this study can be used to direct future biological and fisheries research so that the life histories (including reproductive biology, which was not addressed in this study), ecological interactions, and needs for management of blue rockfish and deacon rockfish can be better understood. This information is particularly important for groundfish fisheries in the California Current because there remain several instances in which historical data pool 2 (or more) species that are now known to be distinct, such as the vermillion rockfish and sunset rockfish complex (Hyde et al., 2008) and the rougheye rockfish and blackspotted rockfish complex (Gharrett et al., 2005, 2006). Although the stock of blue rockfish and deacon rockfish off California was estimated to be slightly below target biomass and the stock off Oregon was well above the reference target (Dick et al. ${ }^{3}$ ), the assumption that the status and population trends of the 2 constituent species in each region are similar remains uncertain. The ability to differentiate morphologically similar species and stocks for assessments is largely contingent on the reliability of the approach used to distinguish them in the fishery; however, data collection programs for both commercial and recreational fisheries in some regions have not yet resolved catch and compositional data to the species level. Future research should therefore focus on collection of sexand species-specific data to facilitate the development of separate stock assessments for each species.

\section{Acknowledgments}

We thank the following colleagues for their assistance: S. Beyer, T. Buell, E. Campbell, C. Columbus, L. Correa, A. Dauble, N. Kashef, T. Laidig, M. McFarland, S. Ralston, P. Rankin, K. Sakuma, S. Sogard, D. Stafford, N. Yochum, and M. Yoklavich. Funding was provided by the National Marine Fisheries Service's Improve a Stock Assessment Program. The authors J. Bizzarro and E. Gilbert-Horvath contributed equally to this manuscript.

\footnotetext{
${ }^{6}$ NMFS (National Marine Fisheries Service). 2018. Pacific coast groundfish fishery 2019-2020 harvest specifications and management measures: analytical document organized as a preliminary draft environmental assessment, $118 \mathrm{p}$. Agenda item E.4, Suppl. rev. attach. 2. Natl. Mar. Fish. Serv., Seattle, WA. [Available from website.]
} 


\section{Literature cited}

Akaike, $\mathrm{H}$.

1974. A new look at the statistical model identification. IEEE Trans. Autom. Control 16:716-723. Crossref

Anderson, E. C., R. S. Waples, and S. T. Kalinowski.

2008. An improved method for predicting the accuracy of genetic stock identification. Can. J. Fish. Aquat. Sci. 65:1475-1486. Crossref

Beamish, R. J.

1979. New information on the longevity of Pacific Ocean perch (Sebastes alutus). J. Fish. Res. Board Can. 36:13951400. Crossref

Belkhir, K. P., P. Borsa, L. Chikhi, N. Raufaste, and F. Bonhomme. 2004. GENETIX 4.05, logiciel sous Windows pour la génétique des populations. Laboratoire génome, populations, interactions. CNRS UMR 5000, Univ. Montpellier II, Montpellier, France. [Available from website.]

Buonaccorsi, V. P., M. Westerman, J. Stannard, C. Kimbrell, E. Lynn, and R. D. Vetter.

2004. Molecular genetic structure suggests limited larval dispersal in grass rockfish, Sebastes rastrelliger. Mar. Biol. 145:779-788. Crossref

Buonaccorsi, V. P., C. A. Kimbrell, E. A. Lynn, and R. D. Vetter.

2005. Limited realized dispersal and introgressive hybridization influence genetic structure and conservation strategies for brown rockfish, Sebastes auriculatus. Conserv. Genet. 6:697-713. Crossref

Burford, M. O.

2009. Demographic history, geographical distribution and reproductive isolation of distinct lineages of blue rockfish (Sebastes mystinus), a marine fish with a high dispersal potential. J. Evol. Biol. 22:1471-1486. Crossref

Burford, M. O., and G. Bernardi.

2008. Incipient speciation within a subgenus of rockfish (Sebastosomus) provides evidence of recent radiations within an ancient species flock. Mar. Biol. 154:701-717. Crossref

Burford, M. O., G. Bernardi, and M. H. Carr.

2011a. Analysis of individual year-classes of a marine fish reveals little evidence of first-generation hybrids between cryptic species in sympatric regions. Mar. Biol. 158:18151827. Crossref

Burford, M. O., M. H. Carr, and G. Bernardi.

2011b. Age-structured genetic analysis reveals temporal and geographic variation within and between two cryptic rockfish species. Mar. Ecol. Prog. Ser. 442:201-215. Crossref

Campana, S. E., M. C. Annand, and J. I. McMillan.

1995. Graphical and statistical methods for determining the consistency of age determinations. Trans. Am. Fish. Soc. 124:131-138. Crossref

Chilton, D. E., and R. J. Beamish.

1982. Age determination methods for fishes studied by groundfish program at the Pacific Biological Station. Can. Spec. Publ. Fish. Aquat. Sci. 60, 102 p.

Cope, J. M., and A. E. Punt.

2011. Reconciling stock assessment and management scales under conditions of spatially varying catch histories. Fish. Res. 107:22-38. Crossref

Cope, J. M., J. DeVore, E. J. Dick, K. Ames, J. Budrick, D. L. Erickson,

J. Grebel, G. Hanshew, R. Jones, L. Mattes, et al.

2011. An approach to defining stock complexes for U.S. West Coast groundfishes using vulnerabilities and ecological distributions. North Am. J. Fish. Manage. 31:589-604. Crossref

Eschmeyer W. N., R. Fricke, and R. van der Laan (eds.).

2017. Catalog of fishes: genera, species, references. [Available from website, accessed October 2017.]
Frable, B. W., D. W. Wagman, T. N. Frierson, A. Aquilar, and B. L. Sidlauskas.

2015. A new species of Sebastes (Scorpaeniformes: Sebastidae) from the northeastern Pacific, with a redescription of the blue rockfish, S. mystinus (Jordan and Gilbert, 1881). Fish. Bull. 113:355-377. Crossref

Gharrett, A. J., A. P. Matala, E. L. Peterson, A. K. Gray, Z. Li, and J. Heifetz.

2005. Two genetically distinct forms of rougheye rockfish are different species. Trans. Am. Fish. Soc. 134:242-260. Crossref

Gharrett, A. J., C. W. Mecklenburg, L. W. Seeb, Z. Li, A. P. Matala,

A. K. Gray, and J. Heifetz.

2006. Do genetically distinct rougheye rockfish sibling species differ phenotypically? Trans. Am. Fish. Soc. 135:792800. Crossref

Gómez-Uchida, D., E. A. Hoffman, W. R. Ardren, and M. A. Banks. 2003. Microsatellite markers for the heavily exploited canary (Sebastes pinniger) and other rockfish species. Mol. Ecol. Notes 3:387-389. Crossref

Harms, J. H., J. A. Benante, and R. M. Barnhart.

2008. The 2004-2007 hook and line survey of shelf rockfish in the Southern California Bight: estimates of distribution, abundance, and length composition. NOAA Tech. Memo. NMFS-NWFSC-95, $110 \mathrm{p}$.

Hess, J. E., P. Chittaro, A. Elz, E. A. Gilbert-Horvath, V. Simon, and J. C. Garza.

2014. Cryptic population structure in the severely depleted cowcod, Sebastes levis. Can. J. Fish. Aquat. Sci. 71:81-92. Crossref

Hicks, A., C. Wetzel, and J. Harms.

2014. The status of rougheye rockfish (Sebastes aleutianus) and blackspotted rockfish (S. melanostictus) as a complex along the U.S. West Coast in 2013, 136 p. Pac. Fish. Manage. Counc., Portland, OR. [Available from website.]

Hyde, J. R., C. A. Kimbrell, J. E. Budrick, E. A. Lynn, and R. D. Vetter. 2008. Cryptic speciation in the vermilion rockfish (Sebastes miniatus) and the role of bathymetry in the speciation process. Mol. Ecol. 17:1122-1136. Crossref

Jiao, Y., C. Hayes, and E. Cortés.

2009. Hierarchical Bayesian approach for population dynamics modelling of fish complexes without species-specific data. ICES J. Mar. Sci. 66:367-377. Crossref

Johns, G. C., and J. C. Avise.

1998. Tests for ancient species flocks based on molecular phylogenetic appraisals of Sebastes rockfishes and other marine fishes. Evolution 52:1135-1146. Crossref

Jordan, D. S., and C. H. Gilbert.

1881. Description of Sebastichthys mystinus. Proc. U.S. Natl. Mus. 4:70-72. Crossref

Kai, Y., K. Nakayama, and T. Nakabo.

2002. Genetic differences among three colour morphotypes of the black rockfish, Sebastes inermis, inferred from mtDNA and AFLP analyses. Mol. Ecol. 11:2591-2598. Crossref

Karpov, K. A., D. P. Albin, and W. H. Van Buskirk.

1995. The marine recreational fishery in northern and central California: a historical comparison (1958-86), status of stocks (1980-86), and effects of changes in the California Current. Calif. Dep. Fish Game, Fish Bull. 176, 192 p.

Kimura, D. K., R. R. Mandapat, and S. L. Oxford.

1979. Method, validity, and variability in the age determination of yellowtail rockfish (Sebastes flavidus), using otoliths. J. Fish. Res. Board Can. 36:377-383. Crossref

Klingbeil, R. A., and E. H. Knaggs.

1976. Southern range extensions of the blue rockfish, Sebastes mystinus; the flag rockfish, $S$. rubrivinctus; and the shortbelly rockfish, $S$. jordani. Calif. Fish Game 62(2):160. 
Laidig, T. E., D. E. Pearson, and L. L. Sinclair.

2003. Age and growth of blue rockfish (Sebastes mystinus) from central and northern California. Fish. Bull. 101:800-808.

Love, M. S.

2011. Certainly more than you want to know about the fishes of the Pacific Coast: a postmodern experience, 650 p. Really Big Press, Santa Barbara, CA.

MacGregor, J. S.

1983. Growth of the blue rockfish (Sebastes mystinus). CalCOFI Rep. 24:216-225.

McClure, R. E.

1982. Neritic reef fishes off central Oregon: aspects of life histories and recreational fishery. M.S. thesis, 94 p. Oregon State Univ., Corvallis, OR.

Miller, D. J., and J. J. Geibel.

1973. Summary of blue rockfish and lingcod life histories; a reef ecology study; and giant kelp, Macrocystis pyrifera, experiments in Monterey Bay, California. Calif. Dep. Fish Game, Fish Bull. 158, 131 p. [Available from website.]

Munk, K. M.

2001. Maximum ages of groundfishes in waters off Alaska and British Columbia and considerations on age determination. Alaska Fish. Res. Bull. 8:12-21.

Orr, J. W., and S. Hawkins.

2008. Species of the rougheye rockfish complex: resurrection of Sebastes melanostictus (Matsubara, 1934) and a redescription of Sebastes aleutianus (Jordan and Evermann, 1898) (Teleostei: Scorpaeniformes). Fish. Bull. 106:111-134.

Paetkau, D., R. Slade, M. Burden, and A. Estoup.

2004. Genetic assignment methods for the direct, real-time estimation of migration rate: a simulation-based exploration of accuracy and power. Mol. Ecol. 13:55-65. Crossref

Park, S. D. E.

2002. Trypanotolerance in West African cattle and the population genetic effects of selection. Ph.D. thesis, 241 p. Trinity College, Dublin, Ireland. [Available from website.]

Pearse, D. E., L. Wooninck, C. A. Dean, and J. C. Garza.

2007. Identification of northeastern Pacific rockfish using multilocus nuclear DNA genotypes. Trans. Am. Fish. Soc. 136:272-280. Crossref

Piry, S., A. Alapetite, J.-M. Cornuet, D. Paetkau, L. Baudouin, and

A. Estoup.

2004. GENECLASS2: a software for genetic assignment and first-generation migrant detection. J. Hered. 95:536-539. Crossref

Pritchard, J. K., M. Stephens, and P. Donnelly.

2000. Inference of population structure using multilocus genotype data. Genetics 155:945-959.

Quattro, J. M., W. B. Driggers III, J. M. Grady, G. F. Ulrich, and

M. A. Roberts.

2013. Sphyrna gilberti sp. nov., a new hammerhead shark (Carcharhiniformes, Sphyrnidae) from the western Atlantic Ocean. Zootaxa 3702:159-178. Crossref
R Core Team.

2016. R: a language and environment for statistical computing. R Foundation for Statistical Computing, Vienna, Austria. [Available from website, accessed October 2016.]

Rannala, B., and J. L. Mountain.

1997. Detecting immigration by using multilocus genotypes. Proc. Natl. Acad. Sci. U.S.A. 94:9197-9201. Crossref

Roques, S., D. Pallotta, J.-M. Sévigny, and L. Bernatchez.

1999. Isolation and characterization of polymorphic microsatellite markers in the North Atlantic redfish (Teleostei: Scorpaenidae, genus Sebastes). Mol. Ecol. 8:685-687. Crossref

Sakuma, K. M., S. Ralston, and V. G. Wespestad.

2006. Interannual and spatial variation in the distribution of young-of-the-year rockfish (Sebastes spp.): expanding and coordinating a survey sampling frame. CalCOFI Rep. 47:127-139.

Sakuma, K. M., J. C. Field, N. J. Mantua, S. Ralston, B. B. Marinovic, and C. N. Carrion.

2016. Anomalous epipelagic micronekton assemblage patterns in the neritic waters of the California Current in spring 2015 during a period of extreme ocean conditions. CalCOFI Rep. 57:163-183.

Schmidt, K. T.

2014. Life history changes in female blue rockfish, Sebastes mystinus, before and after overfishing in central California. M.S. thesis, 94 p. Calif. State Univ., Monterey Bay, CA.

Sekino, M., N. Takagi, M. Hara, and H. Takahashi.

2000. Microsatellites in rockfish Sebastes thompsoni (Scorpaenidae). Mol. Ecol. 9:634-636. Crossref

Shertzer, K. W., and E. W. Williams.

2008. Fish assemblages and indicator species: reef fishes off the southeastern United States. Fish. Bull. 106:257-269.

Tellier, F., J. M. A. Vega, B. R. Broitman, J. A. D. Vásquez, $\mathrm{M}$. Valero, and S. Faugeron.

2011. The importance of having two species instead of one in kelp management: the Lessonia nigrescens complex. Cah. Biol. Mar. 52:455-465.

Tuckey, T., N. Yochum, J. Hoenig, J. Lucy, and J. Cimino.

2007. Evaluating localized vs. large-scale management: the example of tautog in Virginia. Fisheries 32:21-28. Crossref

Venerus, L. A., J. E. Ciancio, C. Riva-Rossi, E. A. Gilbert-Horvath,

A. E. Gosztonyi, and J. C. Garza.

2013. Genetic structure and different color morphotypes suggest the occurrence and bathymetric segregation of two incipient species of Sebastes off Argentina. Naturwissenschaften 100:645-658. Crossref

von Bertalanffy, L.

1957. Quantitative laws in metabolism and growth. Q. Rev. Biol. 32:217-231. 